\title{
Wanda Patrzałek
}

\author{
Uniwersytet Wrocławski \\ Wydział Nauk Społecznych \\ e-mail: wanda.patrzalek@uwr.edu.pl
}

\section{Determinanty stylu życia młodych konsumentów}

\section{Kod JEL: D11}

Słowa kluczowe: konsumpcja, styl życia, zachowania prozdrowotne, młody konsument, zachowania antyzdrowotne

Streszczenie. Celem artykułu jest analiza czynników wpływających na styl życia młodych konsumentów. W kategorii determinant stylu życia będą mieścić się zarówno czynniki zdrowotne, jak i antyzdrowotne. Proporcje udziału tych czynników mogą być zachwiane zwłaszcza w odniesieniu do młodych konsumentów. Egzemplifikację rozważań stanowią badania przeprowadzone pod kierunkiem autorki zrealizowane metodą sondażu diagnostycznego wśród 200 studentów z Uniwersytetu Wrocławskiego i Akademii Wychowania Fizycznego w 2016 roku. Wyniki badań odniesiono do sondaży CBOS-u i Eurobarometru w kontekście zachowań zdrowotnych Polaków.

\section{Wprowadzenie}

Warunkiem niezbędnym do kreowania prozdrowotnego stylu życia jest odpowiedni poziom świadomości konsumenckiej, ale także wdrażanie tych założeń w zachowaniach codziennych i kształtowanie zdrowych nawyków zarówno w odniesieniu do odżywiania, aktywności fizycznej jak i unikania czynników szkodliwych. W Polsce młodzi ludzie wykazują niskie zainteresowanie zdrowiem i zachowaniami prozdrowotnymi mającymi na celu jego ochronę i wzmacnianie. Zachowania zdrowotne kształtują się od wczesnego dzieciństwa szczególnie w okresie socjalizacji pierwotnej. Jednym z głównych czynników warunkujących zdrowie jednostki jest w 50-60\% styl życia i zachowania zdrowotne. 
W artykule omówiono determinanty wpływające na styl życia wśród wrocławskich studentów. Założono hipotetycznie, że poziom świadomości w zakresie czynników prozdrowotnych może być zróżnicowany w zależności od kierunku studiów. $Z$ tego względu badania sondażowe przeprowadzono wśród studentów studiujących w Akademii Wychowania Fizycznego we Wrocławiu i na Wydziale Nauk Społecznych Uniwersytetu Wrocławskiego. Wybór tych grup badawczych wynikał z postawionej hipotezy głównej, że studenci prowadzą antyzdrowotny styl życia. życia. Badania własne prowadzone pod kierunkiem autorki odniesiono do badań porównawczych prowadzonych przez CBOS w Polsce oraz badań Eurobarometru dotyczących zachowań zdrowotnych w krajach Unii Europejskiej.

\section{Styl życia w ponowoczesności}

Współcześnie w rozumieniu stylu życia widoczne są dwa podejścia. Pierwsze $\mathrm{z}$ nich odnosi styl życia do miejsca jednostki w strukturze społecznej wyznaczonego przez pełnione przez nią role społeczne, za którymi kryją się indywidualne manifestacje pozycji społecznych związanych z preferencjami wzorców zachowań, przedmiotów (Weber, 2002; Bourdieu, 2006, Veblen, 2008). Drugie z nich traktuje styl życia jako działania zrutynizowane, ale osadzone w pryzmacie refleksyjności powiązanej z kreowaniem własnej tożsamości. W obrębie tego nurtu pozostają ujęcia A. Giddensa traktującego styl życia jako indywidualną lub zbiorową ekspresję. Autor definiuje styl życia jako „mniej lub bardziej zintegrowany zespół praktyk, które podejmuje jednostka nie tylko dlatego, że są użyteczne, ale także dlatego, że nadają materialny kształt poszczególnym narracjom tożsamościowym. (...) Style życia są zrutynizowanymi praktykami, które odpowiadają nawykom żywieniowym, sposobom ubierania się, zachowania i zwyczajom spotykania się w ulubionych miejscach. Jednak rutynowe działania jednostki podlegają refleksji i mogą ulegać zmianom z uwagi na zmienność indywidualnej tożsamości” (Giddens, 2002, s. 113).

Styl życia kształtuje się w procesie socjalizacji pierwotnej i wynika $\mathrm{z}$ bezpośrednich relacji między jednostką a jej środowiskiem rodzinnym, rówieśniczym, szkolnym. Stanowi element kulturowego oddziaływania na jednostkę wyposażający ją w określone wartości, nawyki, normy i wzorce zachowań.

Operacyjną definicję stylu życia odnoszoną do praktyk życia codziennego zaproponował A. Siciński. Autor dokonał typologii stylów życia określanej mianem homo eligens (Siciński, 1988, s. 57), nietracącej nadal aktualności, wyróżniającej:

- styl życia w sytuacji ograniczonych możliwości dokonywania wyborów,

- styl życia polegający na unikaniu wyborów,

- styl życia będący poszukiwaniem drogi życiowej, naczelnych wartości,

- styl życia nastawiony na działanie jako na cel sam w sobie, 
- styl życia nastawiony na zachowawczy skutek działań,

- styl życia nastawiony na działania prowadzące do zmiany.

Przez styl życia będziemy rozumieć określoną strategię zachowań jednostek związaną z codziennymi decyzjami w zakresie nauki, pracy, konsumpcji, czasu wolnego, snu, ale także preferencji życiowych determinujących indywidualne praktyki i gusty.

A. Gidens uważa, że w społeczeństwach ponowoczesnych prowadzenie określonego stylu życia stało się konieczne, a często wymagalne. Jednostki stają się konsumentami zdrowia, czynnie dbając o swoje samopoczucie i zdrowie (Giddens 2002).

\section{Determinanty stylu życia}

Styl życia zależy od wielu czynników, które można podzielić na zdrowotne i antyzdrowotne. Jednym z najważniejszych czynników determinujących zdrowie człowieka są właściwe nawyki żywieniowe. Odpowiedni sposób odżywiania się zapobiega większości chorób. Szacuje się, że istnieje około 30-50 jednostek chorobowych bądź odchyleń od zdrowia, występujących często w populacji, których przyczyną jest niezadowalająca jakość żywności i sposobu odżywiania (Ostrowska, 1999, s. 52).

L.W. Green i M.W. Kreuter (1999) do najważniejszych czynników kształtujących zachowania zdrowotne zaliczyli:

a) czynniki predysponujące - w skład których wchodzą umiejętności, kompetencje, przekonania i postawy;

b) czynniki umożliwiające - predyspozycje istotne dla zdrowia, przepisy prawne, powszechność i kondycja opieki zdrowotnej;

c) czynniki wzmacniające - normy obyczajowe - zgoda lub jej brak na określone działanie w otoczeniu bliskich, w szkole i pracy; czynniki te są powiązane $\mathrm{z}$ warunkami, w jakich żyje człowiek.

Jednym z zasadniczych czynników warunkujących zdrowie jest sposób odżywiania się. Podstawą zdrowego żywienia jest jego regularność polegająca na stosowaniu reguł w spożywaniu posiłków. Należą do nich spożywanie jedzenia w odpowiednich odstępach czasu, o stałych porach dnia oraz rozłożenia kaloryczności na konkretne posiłki. Liczba posiłków zalecana przez Instytut Żywienia i Żywności wynosi pięć dziennie.

Organizm człowieka od początku rozwoju ludzkości przystosował się do pokarmów składających się głównie z produktów roślinnych. Dopiero na początku rewolucji przemysłowej w XIX w. nastąpiła, początkowo powolna, a następnie drastyczna zmiana składu diety człowieka, polegająca na zwiększeniu w niej zawartości tłuszczu zwierzęcego i zmniejszeniu udziału składników roślinnych. 
W opinii Polaków do najważniejszych czynników prozdrowotnych należy (tab. 1) zdrowe odżywianie się oparte głównie na konsumpcji dużej ilości warzyw i owoców przy ograniczaniu spożycia tłuszczów zwierzęcych (50\% wskazań), aktywności fizycznej (46\%, w tym regularne ćwiczenia i aktywny wypoczynek), regularne wizyty u lekarza (34\%), ale także ograniczenie używek $(30 \%$, w tym niepalenie papierosów i niepicie alkoholu) oraz unikanie sytuacji stresogennych $(29 \%)$.

Tabela 1

Działania prozdrowotne w opinii Polaków (w \%)

\begin{tabular}{|l|c|}
\hline \multicolumn{1}{|c|}{ Czynniki prozdrowotne } & Odsetek \\
\hline $\begin{array}{l}\text { Zdrowe odżywianie się (dużo warzyw i owoców, ograniczanie tłuszczów } \\
\text { zwierzęcych) }\end{array}$ & 50 \\
\hline Regularne wizyty u lekarza & 34 \\
\hline Unikanie sytuacji nerwowych, stresowych & 29 \\
\hline Regularne uprawianie gimnastyki, biegi itp. & 25 \\
\hline $\begin{array}{l}\text { Spędzanie wolnych dni, wolnego czasu na aktywnym wypoczynku (spa- } \\
\text { cery, wycieczki rowerowe itp.) }\end{array}$ & 23 \\
\hline Niepalenie papierosów & 21 \\
\hline Niepicie alkoholu & 9 \\
\hline Regularne zażywanie preparatów lub tabletek witaminowych & 3 \\
\hline Inne & 1 \\
\hline
\end{tabular}

Procenty nie sumują się do 100, gdyż respondenci mogli wskazać więcej niż jedno działanie Źródło: CBOS, 2012, s. 4.

Ważnym czynnikiem warunkującym zdrowy styl życia jest jakość i długość snu. Zgodnie z zaleceniami Światowej Organizacji Zdrowia przyjmuje się, że normą zdrowotną dla dorosłego człowieka jest 7-8 godzin snu. Efektywność snu warunkowana jest demograficznie. W Polsce w ciągu ostatnich 10 lat problem zaburzeń snu i bezsenności u młodych dorosłych znacznie się nasilił i dotyka on aż $60 \%$ osób poniżej 25. roku życia. Badania pokazują, że studenci sygnalizują problemy z zasypianiem, dodatkowo sen nie przynosi odpoczynku. Czynnikiem utrudniającym i przyczyną bezsenności są zajęcia na uczelni, które trwają czasem nawet do późnych godzin wieczornych (Błońska, Gotlib, 2012, s. 485-497).

Okres młodości wyzwala wiele cech niezależności związanych z działaniami ryzykownymi w kontekście zdrowia i realizowanego stylu życia. Młodzież studencka zmieniająca $\mathrm{w}$ trakcie studiów miejsce zamieszkania staje przed nowymi wyzwaniami wymagającymi właściwej koordynacji wielu działań, co nie pozostaje bez wpływu na zmianę stylu życia. Jednym ze złych nawyków żywieniowych studentów jest sięganie po różnego rodzaju przekąski (chipsy, chrupki, słodycze). Codziennie sięga po nie 28,6\% studentek i 35,6\% studentów. Z badań prowadzonych w tej grupie młodych konsumentów wynika, że większość z nich 
nie stosuje się do zasad zdrowego żywienia (Stefańska, Ostrowska, Radziejewska, Kardasz, 2010, s. 585-590).

Ważnym czynnikiem zdrowego stylu życia jest aktywność fizyczna. Jej wzrost powoduje obniżenie ryzyka wielu chorób i poprawę jakości życia. Nowoczesne technologie stanowiące podstawę komunikacji wśród ludzi młodych wykluczyły wiele ich form aktywności i spowodowały obniżenie motywacji do zajęć poza domem. Z badań CBOS-u dotyczącego aktywności fizycznej Polaków wynika, że 34\% respondentów nie podejmuje żadnych form aktywności fizycznej. Wśród osób aktywnych fizycznie 40\% respondentów robiło to regularnie, zaś 26\% sporadycznie (CBOS, 2013, s. 1). Na tym tle Polacy wypadają gorzej niż średnia w Unii Europejskiej. Badania Eurobarometru wskazują, że 25\% Europejczyków nie wykonuje żadnych ćwiczeń fizycznych i nie uprawia sportu ( $B a$ danie..., 2010).

\section{Uwarunkowania stylu życia w świetle badań własnych}

W badaniach własnych metodą sondażu diagnostycznego dokonano doboru warstwowego respondentów wśród studentów Uniwersytetu Wrocławskiego i studentów Akademii Wychowania Fizycznego we Wrocławiu. Dobór kierunku studiów na poszczególnych uczelniach oparty był na dychotomicznej zasadzie treści zawierających $\mathrm{w}$ programach nauczania informacje prozdrowotne w Akademii Wychowania Fizycznego i niezawierających takich treści na kierunkach w Uniwersytecie Wrocławskim. Badania zrealizowano w 2016 roku na próbie 200 respondentów techniką ankiety skategoryzowanej wśród 52\% studentów Uniwersytetu Wrocławskiego i 48\% studentów Akademii Wychowania Fizycznego we Wrocławiu. Ze względu na złożenia merytoryczne opracowania średnia wieku badanych to przedział 18-21 lat.

Wśród determinant stylu życia studentów analizie poddano takie czynniki prozdrowotne, jak: sposób odżywiania, aktywność fizyczną, jakość snu oraz antyzdrowotne - stosowanie używek oraz stres.

W badaniach postawiono hipotezę, że w stylu życia studentów dominują czynniki antyzdrowotne. Wśród badanych najwięcej (38\%) studentów nie jest zadowolonych z obecnych nawyków żywieniowych. Analiza wykazała również różnice w ocenie ze względu na płeć badanych. Większość studentek zadeklarowało zadowolenie ze swoich nawyków żywieniowych - 39\%, natomiast aż 47\% studentów nie jest zadowolonych ze swoich obecnych nawyków żywieniowych (rys. 1).

Do nieodpowiednich nawyków żywieniowych należy nieregularność posiłków. W badanej populacji zarówno mężczyźni, jak i kobiety (36\% respondentów) nie spożywają posiłków o regularnych porach dnia i nie ma różnic w tym zakresie 
pomiędzy studentami dwóch badanych uczelni. Niepokojące jest zjawisko dotyczące wysokiej liczby studentów spożywających jedzenie typu fast food - 82\% respondentów spożywa tego typu żywność.

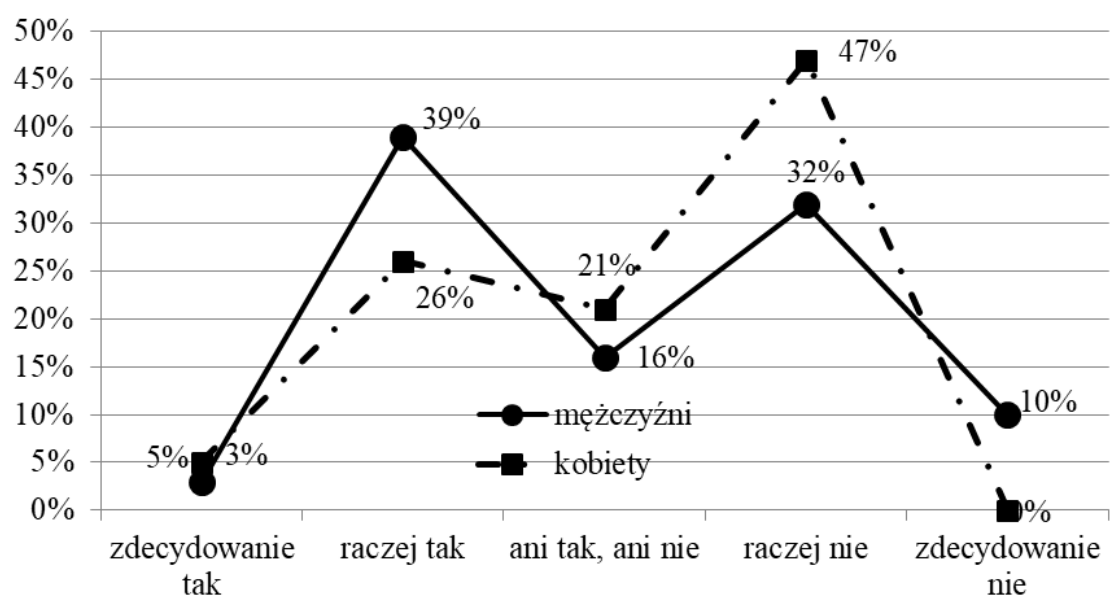

Rysunek 1. Ocena nawyków żywieniowych wśród respondentów

Źródło: badania pod kierunkiem autorki, 2016.

Do ważnych czynników zdrowego stylu życia należy aktywność fizyczna. Wśród respondentów widoczna jest wyraźna różnica między uczelniami. Wyższą aktywnością fizyczną wykazują się studenci Akademii Wychowania Fizycznego ćwiczący w $67 \%$ kilka razy w tygodniu, a 33\% respondentów codziennie. Natomiast studenci Uniwersytetu Wrocławskiego uprawiają aktywność fizyczną najczęściej kilka razy w tygodniu (54\%), zaś codziennie, podobnie jak i raz na tydzień, wskazało $12 \%$ badanych (rys. 2). Do najbardziej preferowanych form aktywności fizycznej wśród mężczyzn należą zajęcia na siłowni (38\% wskazań), zaś wśród kobiet - fitness (19\% wskazań), bieganie (18\%) i spacer (16\%).

Większość studentów (62\%) z obu uczelni była zgodna co do tego, że nie ma problemów z zasypianiem. Natomiast $48 \%$ studentów objętych badaniem przyznało, że często odczuwa senność w ciągu dnia. Wyraźnie częściej studenci UWR odczuwają senność w ciągu dnia $-73 \%$ niż studenci AWF $-21 \%$.

Do czynników antyzdrowotnych należą w grupie młodych konsumentów używki i stres. Najczęściej respondenci sięgają po alkohol (58\%) oraz kawę (60\%). Studenci sięgają po alkohol i papierosy celem lepszej zabawy, rozluźnienia, przyjemności oraz odstresowania. Badani respondenci odczuwają stres bez względu na rodzaj uczelni, natomiast poziom jego odczuwania zależy od płci. Sytuacje, które wywołują największy stres, to kolokwia i egzaminy (54\%) oraz wystąpienia publiczne (22\%). 


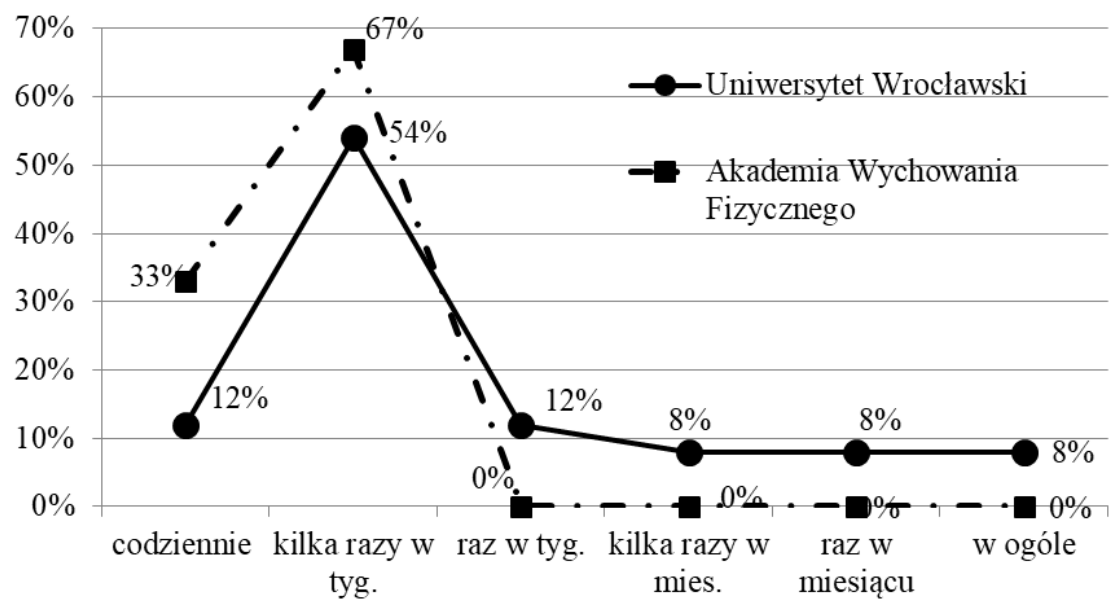

Rysunek 2. Aktywność fizyczna respondentów

Źródło: badania pod kierunkiem autorki, 2016.

Większość studentek (74\%) odczuwa stres najczęściej na poziomie zdecydowanym $-48 \%$. Wśród mężczyzn odsetek ten wynosi 53\%, przy czym znacznie niższy wskaźnik jest zdecydowanego poziomu jego odczuwania - 26\% (rys. 3).

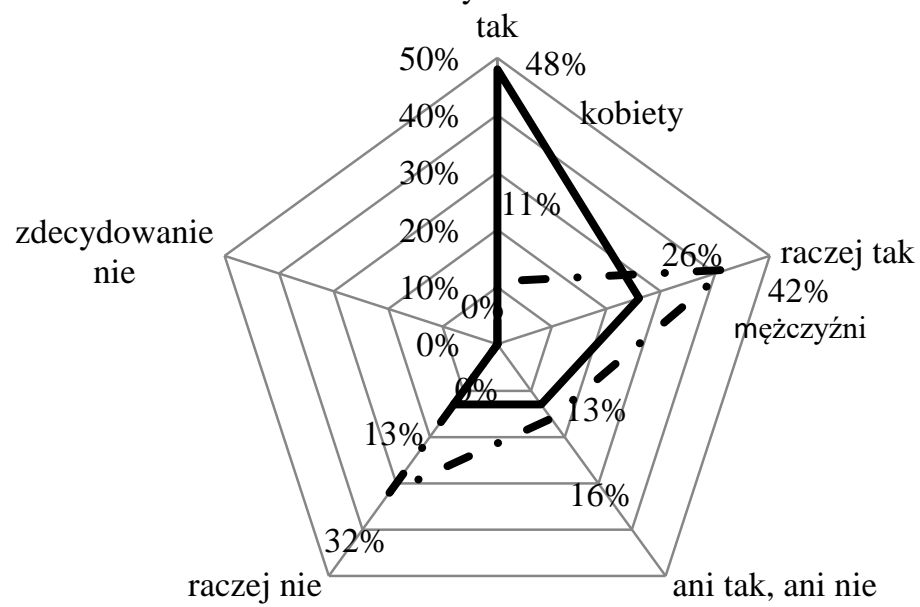

Rysunek 3. Poziom stresu wśród respondentów ze względu na płeć

Źródło: badania pod kierunkiem autorki, 2016.

Najczęściej występującymi reakcjami na stres wśród studentów są bóle brzucha, pocenie się, drżenie rąk, załamywanie głosu oraz zaczerwienienia na 
twarzy. Wśród antystresorów pomagających radzić sobie w sytuacjach stresowych większość studentów (55\%) wymieniało relaks, pozostała część sięga po używki - 35\%, zaś 5\% osób zażywa leki uspokajające.

\section{Podsumowanie}

W artykule przedstawiono wpływ czynników zdrowotnych, takich jak: nawyki żywieniowe, regularność spożywania posiłków, aktywność fizyczna, oraz antyzdrowotnych: jedzenie typu fast food, niewyspanie, używki i stres, w grupie młodych konsumentów, do których zaliczono studentów pierwszych dwóch lat studiów Uniwersytetu Wrocławskiego i Akademii Fizycznej.

$\mathrm{Z}$ analizy badań własnych, jak i badań CBOS-u i Eurobarometru wynika, że znacznie wyższa jest świadomość znaczenia zdrowego stylu życia dla jednostki niż codzienne praktyki i zachowania konsumenckie. W badaniach deklaratywnych prowadzonych przez CBOS wśród Polaków istnieje przekonanie o dużym znaczeniu zdrowego odżywiania się i konieczności unikania sytuacji stresowych i używek. Natomiast rzeczywiste zachowania, co potwierdzają badania Eurobarometru i badania własne, aktywność fizyczna Polaków jest duża niższa niż średnia w krajach Unii Europejskiej.

Do niekorzystnych nawyków wśród młodych konsumentów należą jedzenie typu fast food, nieregularność posiłków, ale także senność w czasie dnia. Na obniżanie jakości stylu życia ludzi młodych wywiera stres związany z kształceniem się, ale także sięganie po używki i ograniczanie aktywności fizycznej wynikające z przemian technologicznych i siedzącego trybu życia.

Wzrost znaczenia czynników prozdrowotnych podnoszących jakość życia i wydłużających czas jego trwania będzie kształtować się pod wpływem nowych trendów w konsumpcji, do których należą zwłaszcza dekonsumpcja i ekologizacja konsumpcji (Patrzałek, 2016, s. 160). Ważne znaczenie w kreowaniu prozdrowotnych wzorców zachowań wśród młodych konsumentów będzie mieć edukacja nastawiona na wdrażanie właściwych norm żywieniowych uwzględniających rodzaj aktywności w tych grupach społecznych rozpoczynająca się już od socjalizacji pierwotnej. Podstawę tych działań stanowi racjonalizacja konsumpcji (Bywalec, 2017, s. 278) obejmująca wszystkie aspekty funkcjonowania młodych konsumentów wdrażająca już od najmłodszych lat odpowiednie nawyki i aspiracje w dziedzinie konsumpcji.

\section{Bibliografia}

Badanie Eurobarometru ujawniło duże różnice $w$ podejściu do sportu $i$ aktywności fizycznej (29.03.2010). Pobrano z: www.europa.eu/rapid/press-release_IP-10-383_pl.htm (9.05.2017).

Błońska, B.K., Gotlib, J. (2012). Występowanie zaburzeń snu wśród studentów. Medical Review, 4, 485-497. 
Bywalec, Cz. (2017). Gospodarstwa domowe. Ekonomika. Finanse. Konsumpcja. Kraków: Wydawnictwo Uniwersytetu Ekonomicznego w Krakowie.

CBOS (2012). Polacy o swoim zdrowiu oraz prozdrowotnych zachowaniach i aktywnościach. Raport z badań BS/110/2012. Pobrano z: www.cbos.pl/SPISKOM.POL/2012/K_110_12.PDF (8.05.2017).

CBOS (2013). Aktywność fizyczna Polaków. Raport z badań BS/129/2013. Pobrano z: www.cbos.pl/SPISKOM.POL/2013/K_129_13.PDF (9.05.2017).

Giddens, A. (2002). Nowoczesność i tożsamość. ,Ja” i spoleczeństwo w epoce późnej nowoczesności. Warszawa: Wydawnictwo Naukowe PWN.

Green, L.W., Kreuter, M.W. (1999). Health promotion planning: An educational and ecological approach. California: Mayfield Publishing Company.

Ostrowska, A. (1999). Styl życia a zdrowie. Warszawa: Wydawnictwo IFiS PAN.

Patrzałek, W. (2016). Proekologiczne zachowania gospodarstw domowych. W: Marketing i Zarzadzanie, 3 (44), 157-166.

Siciński, A. (red.). (1988). Style życia w miastach polskich (u progu kryzysu). Wrocław: Zakład Narodowy im. Ossolińskich.

Stefańska, E., Ostrowska, L., Radziejewska, I., Kardasz, M. (2010). Sposób żywienia studentów Uniwersytetu Medycznego w Białymstoku w zależności od miejsca zamieszkania w trakcie studiów. Problemy Higieny i Epidemiologii, 91 (4), 585-590.

\section{The Determinants of Young Consumer's Lifestyle}

Keywords: consumption, lifestyle, healthy behaviors, young consumer, anti-healthy behaviors

Summary. The main objective of the paper is analysis of the factors influencing the lifestyle among young consumers. The lifestyle determinant category includes both health as well as anti-health factors. The typical proportion of these factors can be disturbed, especially considering young consumers. An exemplification of this approach constitutes the research conducted by the author which are based on diagnostic survey method, where opinions of 200 students from University of Wrocław and the University School of Physical Education in Wroclaw_in 2016 are taken into consideration. The results of these studies are related to the $\mathrm{CBOS}^{-}$data and the Eurobarometer surveys in relation to Polish people health behaviors.

Translated by Wanda Patrzałek

\section{Cytowanie}

Patrzałek, W. (2017). Determinanty stylu życia młodych konsumentów. Marketing i Zarządzanie, 2 (48), 63-71. DOI: 10.18276/miz.2017.48-06. 